\title{
Efficacy of forced-air warming systems with full body blankets
}

\author{
[Efficacité des systèmes de chauffage à air pulsé avec des couvertures à champ
}

complet]

Anselm Bräuer PhD, ${ }^{*}$ Michael J.M. English FRCA, $†$ Nicolas Steinmetz, ${ }^{*}$ Nadja Lorenz MD, ${ }^{*}$ Thorsten Perl MD, ${ }^{*}$ Wolfgang Weyland PhD,‡ Michael Quintel PhD*

Purpose: Postoperative hypothermia after cardiac surgery is still a common problem often treated with forced-air warming. This study was conducted to determine the heat transfer efficacy of I I forced-air warming systems with full body blankets on a validated copper manikin.

Methods: The following systems were tested: I) Bair Hugger ${ }^{\circledR}$ 505; 2) Bair Hugger ${ }^{\circledR} 750$; 3) Life-Air 1000 S; 4) Snuggle Warm ${ }^{\circledR}$; 5) Thermacare ${ }^{\circledR}$; 6) Thermacare ${ }^{\circledR}$ with reusable Optisan ${ }^{\circledR}$ blanket; 7) WarmAir ${ }^{\circledR}$; 8) Warm-Gard ${ }^{\circledR}$; 9) WarmGard ${ }^{\circledR}$ and reusable blanket; 10) WarmTouch ${ }^{\circledR}$; and II) WarmTouch ${ }^{\circledR}$ and reusable blanket. Heat transfer of forced-air warmers can be described as follows: $\dot{Q}=\mathrm{h} \cdot \Delta \mathrm{T} \cdot \mathrm{A}$.

Where $\dot{Q}=$ heat flux $(\mathrm{W}), \mathrm{h}=$ heat exchange coefficient

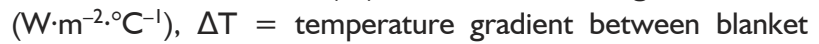
and manikin surface $\left({ }^{\circ} \mathrm{C}\right), \mathrm{A}=$ covered area $\left(\mathrm{m}^{2}\right)$. Heat flux per unit area and surface temperature were measured with 16 heat flux transducers. Blanket temperature was measured using 16 thermocouples. The temperature gradient between blanket and surface $(\Delta T)$ was varied and $h$ was determined by linear regression analysis. Mean $\Delta \mathrm{T}$ was determined for surface temperatures between $32^{\circ} \mathrm{C}$ and $38^{\circ} \mathrm{C}$. The covered area was estimated to be $1.21 \mathrm{~m}^{2}$.

Results: For the II devices, heat transfers of $30.7 \mathrm{~W}$ to $77.3 \mathrm{~W}$ were observed for surface temperatures of $32^{\circ} \mathrm{C}$, and between $-8.8 \mathrm{~W}$ to $29.6 \mathrm{~W}$ for surface temperatures of $38^{\circ} \mathrm{C}$.

Conclusion: There are clinically relevant differences between the tested forced-air warming systems with full body blankets. Several systems were unable to transfer heat to the manikin at a surface temperature of $38^{\circ} \mathrm{C}$.
CAN J ANESTH $2007 / 54: 1 /$ pp 34-41

Objectif: L'hypothermie postopératoire suivant une chirurgie cardiaque est encore un problème courant, souvent traité à l'aide de couverture chauffante à air pulsé. Cette étude a été menée afin de déterminer l'efficacité du transfert de chaleur de II systèmes de chauffage à air pulsé avec des couvertures sur un mannequin de cuivre validé.

Méthodes : Les systèmes suivants ont été testés : I) Bair Hugger ${ }^{\circledR}$ 505; 2) Bair Hugger ${ }^{\circledR} 750$; 3) Life-Air 1000 S; 4) Snuggle Warm ${ }^{\circledR}$; 5) Thermacare ${ }^{\circledR}$; 6) Thermacare ${ }^{\circledR}$ avec couverture réutilisable Optisan ${ }^{\circledR}$; 7) WarmAir $\AA$; 8) Warm-Gard $\AA$; 9) Warm-Gard $\AA$ et couverture réutilisable ; 10) WarmTouch ${ }^{\circledR}$; et II) WarmTouch ${ }^{\circledR}$ et couverture réutilisable. Le transfert de chaleur de systèmes de chauffage à air pulsé peut être décrit de cette façon : $\dot{Q}=h \cdot \Delta T$ - $A$, où $\dot{Q}=$ flux de chaleur $(W), h$ = coefficient d'échange de

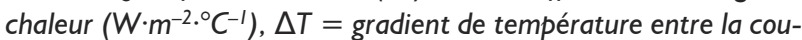
verture et la surface du mannequin $\left({ }^{\circ} \mathrm{C}\right), A=$ aire couverte $\left(\mathrm{m}^{2}\right)$. Le flux de chaleur par unité d'aire et la température de surface ont été mesurés à l'aide de 16 capteurs de flux de chaleur. La température de la couverture a été mesurée à l'aide de 16 thermocouples. Le gradient de température entre la couverture et la surface $(\Delta T)$ était modifié et $h$ a été déterminé par une analyse de régression linéaire. Le $\Delta T$ moyen a été déterminé entre $32^{\circ} \mathrm{C}$ et $38^{\circ} \mathrm{C}$ pour les températures de surface. L'aire couverte a été estimée à $I, 21 \mathrm{~m}^{2}$.

Résultats : Pour les I/ appareils, des transferts de chaleur de 30,7 W à 77,3 W ont été observés pour une température de surface

From the Department of Anesthesiology, ${ }^{*}$ Emergency and Intensive Care Medicine, University of Göttingen, Germany; the Department of Anesthesia, $†$ Montreal General Hospital and McGill University, Montreal, Quebec, Canada; and the Department of Anesthesia and Intensive Care Medicine, Evangelisches Bethesda-Krankenhaus Essen, Germany.

Address correspondence to: PD Dr. med. Anselm Bräuer, Department of Anesthesiology, Emergency and Intensive Care Medicine, University of Göttingen, Robert-Koch-Str. 40, D-37075 Göttingen, Germany. Phone: ++49-551-39-8826; Fax: ++49-551-39-8676; E-mail: abraeue@gwdg.de

Disclosure: Principal financial support for this study was provided by departmental sources. The work was also partially supported through grants-in-aid in the amount of $500 €$ for each company whose product was evaluated. The companies were explicitly restricted from having any influence on study design, data analysis or data interpretation. The laboratory has been funded, in part, by Augustine Medical, Mallinckrodt, Rüsch and several other companies which manufacture and distribute body warming devices. However, no author has a financial interest in the products which were evaluated.

Accepted for publication June 23, 2006.

Revision accepted October 19, 2006. 
de $32^{\circ} \mathrm{C}$, et entre $-8,8 \mathrm{~W}$ et $29,6 \mathrm{~W}$ pour une température de surface de $38^{\circ} \mathrm{C}$.

Conclusion : Il existe des différences cliniquement significatives entre les systèmes de chauffage à air pulsé testés avec des couvertures à champ complet. De nombreux systèmes ont été incapables de transférer la chaleur au mannequin à une température de surface de $38^{\circ} \mathrm{C}$.

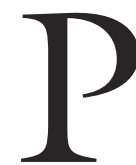
OSTOPERATIVE hypothermia can occur after cardiac surgery as a consequence of inadequate intraoperative warming strategies and the physiological trespasses of cardiopulmonary bypass. During cardiac surgery, forced-air warming is only possible after completion of saphenous vein harvesting with special sterile blankets. This method reduces heat losses after cessation of cardiopulmonary bypass, but cannot prevent temperature afterdrop completely. ${ }^{1}$ Other methods, including sodium nitroprusside induced vasodilatation, and increased pump flow during rewarming on cardiopulmonary bypass, ${ }^{1}$ or extended rewarming on cardiopulmonary bypass ${ }^{2}$ are also not entirely effective in preventing postoperative hypothermia. Therefore, hypothermia after cardiac surgery remains a significant problem, ${ }^{3-8}$ for which external warming devices are usually applied in the early postoperative setting.

The following study compared the efficacy of 11 forced-air warming systems with full body blankets using a validated copper manikin of the human body. The primary outcome variable was the heat transfer at surface temperatures of $32^{\circ} \mathrm{C}$ to $38^{\circ} \mathrm{C}$.

\section{Methods}

The following forced-air warming systems were tested:

- Bair Hugger ${ }^{\circledR}$ Model 505 Warming Unit and full body blanket model 300 (Arizant Healthcare Inc., Eden Prairie, MN, USA)

- Bair Hugger® Model 750 Warming Unit and full body blanket model 300 (Arizant Healthcare Inc., Eden Prairie, MN, USA)

- Life-Air 1000 S Warming Unit and Soft-Flex full body blanket (Rüsch GmbH, Kernen, Germany)

- Snuggle Warm® SW-3000 Power Unit and full body blanket SW-2001 (Smiths Industries Medical Systems, Irvine, CA, USA)

- Thermacare ${ }^{\circledR}$ TC3003 Power Unit and full body blanket (Gaymar Industries, Orchard Park, NY, USA)

- Thermacare® ${ }^{\circledR}$ TC3003 Power Unit (Gaymar Industries, Orchard Park, NY, USA) and reusable Optisan ${ }^{\circledR}$ full body blanket (Rüsch GmbH, Kernen, Germany)
- WarmAir ${ }^{\circledR}$ Model 134 and full body FiltredFlo ${ }^{\mathrm{TM}}$ blanket (Cincinnati Sub-Zero Products, Cincinnati, $\mathrm{OH}, \mathrm{USA})$

- Warm-Gard® Portable Warmer and full body blanket (Luis Gibeck AB, Upplands Väsby, Sweden)

- Warm-Gard® Portable Warmer and reusable full body blanket (Luis Gibeck AB, Upplands Väsby, Sweden)

- WarmTouch ${ }^{\mathrm{TM}}$ Patient Warming System 5800 and CareQuilt ${ }^{\mathrm{TM}}$ full body blanket (Mallinckrodt Medical Inc., St. Louis, MO, USA)

- WarmTouch ${ }^{\mathrm{TM}}$ patient warming system 5800 and reusable MultiCover ${ }^{\mathrm{TM}}$ full body blanket (Mallinckrodt Medical Inc., St. Louis, MO, USA).

\section{Measurement of environmental conditions}

Room temperature, relative humidity and air velocity were measured in the middle of the room and near the wall using a thermoanemometer (VELOCICALC PLUS TSI ${ }^{\circledR}$ Model 8388-M-D, TSI Inc., St. Paul, $\mathrm{MN}, \mathrm{USA})$.

\section{The manikin}

The manikin consisted of six copper tubes painted matt-black. Two tubes served as arms (circumference $330 \mathrm{~mm}$, length $705 \mathrm{~mm}$ ), two as legs (circumference $485 \mathrm{~mm}$, length $750 \mathrm{~mm}$ ), one as the head (circumference $500 \mathrm{~mm}$, length $330 \mathrm{~mm}$ ) and one as the trunk (circumference $840 \mathrm{~mm}$, length $740 \mathrm{~mm}$ ). The total surface area of all tubes was $1.98 \mathrm{~m}^{2}$. In order to set surface temperature and achieve steady-state conditions, water mattresses (Maxi-Therm ${ }^{\circledR}$, Cincinnati Sub-Zero Products Inc., Cincinnati, OH, USA) were bonded to the inner surface of the copper tubes. The circulating water was warmed and cooled by a hypohyperthermia system (Hico-Variotherm 530, Hirtz \& Co. Hospitalwerk, Cologne, Germany).

\section{Heat flow delivered to the blanket}

Forced-air warming systems consist of a power unit incorporating an electrical heater and a fan to generate an air flow that is delivered downstream to a blanket. Each manufacturer's heater was connected to the corresponding full body blanket. Temperature control was set to the highest temperature, with exception of the Thermacare ${ }^{\circledR}$ power unit, where the highest temperature recommended for anesthetized patients was used. This temperature setting was used throughout the study and was called the "maximum temperature". The air flow control of the Warm-Gard ${ }^{\circledR}$ power unit was set to "high". All other power units have only one flow rate. The air delivery hose from the power unit to the blanket was fully extended. The blankets were 
then positioned on the manikin and covered with two layers of cotton sheets.

\section{Measurement of nozzle temperature and air velocity at the nozzle}

Nozzle temperature and air velocity at the nozzle were measured using a thermoanemometer (VELOCICALC PLUS TSI ${ }^{\circledR}$ Model 8388-M-D, TSI Inc., St. Paul, MN, USA). Both parameters were measured directly at an adapter which connected the nozzle to the blanket and which contained a mesh (mesh size $1 \mathrm{~mm} \times$ $\mathrm{l} \mathrm{mm}$ ) to create laminar air flow. Air temperature and air velocity were measured at three defined positions evenly distributed on the diameter. The average of these three measurements was taken as the average air temperature and air velocity. Air velocity was multiplied by the area of the adapter to calculate air flow.

Heat flow produced by the power units was calculated as follows:

$$
\dot{\mathrm{Q}}=\mathrm{F} \cdot \Delta \mathrm{T} \cdot \mathrm{c} \cdot \rho
$$

where:

$\dot{\mathrm{Q}}=$ heat flow $(\mathrm{W})$

$\mathrm{F}=$ air flow $\left(\mathrm{L} \cdot \mathrm{sec}^{-1}\right)$

$\Delta \mathrm{T}=$ temperature gradient between the nozzle and the room $\left({ }^{\circ} \mathrm{C}\right)$

$\mathrm{c}=$ specific heat capacity of $\operatorname{air}\left(\mathrm{J} \cdot \mathrm{g}^{-1}{ }^{\circ} \mathrm{C}^{-1}\right)$

$\rho=$ density of air at the nozzle temperature $\left(\mathrm{g} \cdot \mathrm{L}^{-1}\right)$

The values of the specific heat capacity of air and the density of air at the nozzle temperature were taken from standard tables. ${ }^{9}$

\section{Heat exchange at the manikin}

The basic equation for temperature-dependent heat transfer is:

$$
\begin{aligned}
& \dot{\mathrm{Q}}=\mathrm{h} \cdot \Delta \mathrm{T} \cdot \mathrm{A}(\text { Eqn. } \mathrm{l}) \\
& \text { where: } \\
& \dot{\mathrm{Q}}=\text { heat flow }(\mathrm{W}) \\
& \mathrm{h}=\text { heat exchange coefficient }\left(\mathrm{W} \cdot \mathrm{m}^{-2} \cdot{ }^{\circ} \mathrm{C}^{-1}\right) \\
& \Delta \mathrm{T}=\text { temperature gradient }\left({ }^{\circ} \mathrm{C}\right) \\
& \mathrm{A}=\operatorname{area}\left(\mathrm{m}^{2}\right)
\end{aligned}
$$

This equation can be applied to describe the heat exchange process between a forced-air warming blanket and the manikin. The heat exchange coefficient $\mathrm{h}$ defines the efficacy of all the heat exchange mechanisms (radiation, convection, and conduction) between the blanket and the manikin, whereas the temperature gradient $\Delta \mathrm{T}$ is the driving force of this heat exchange.

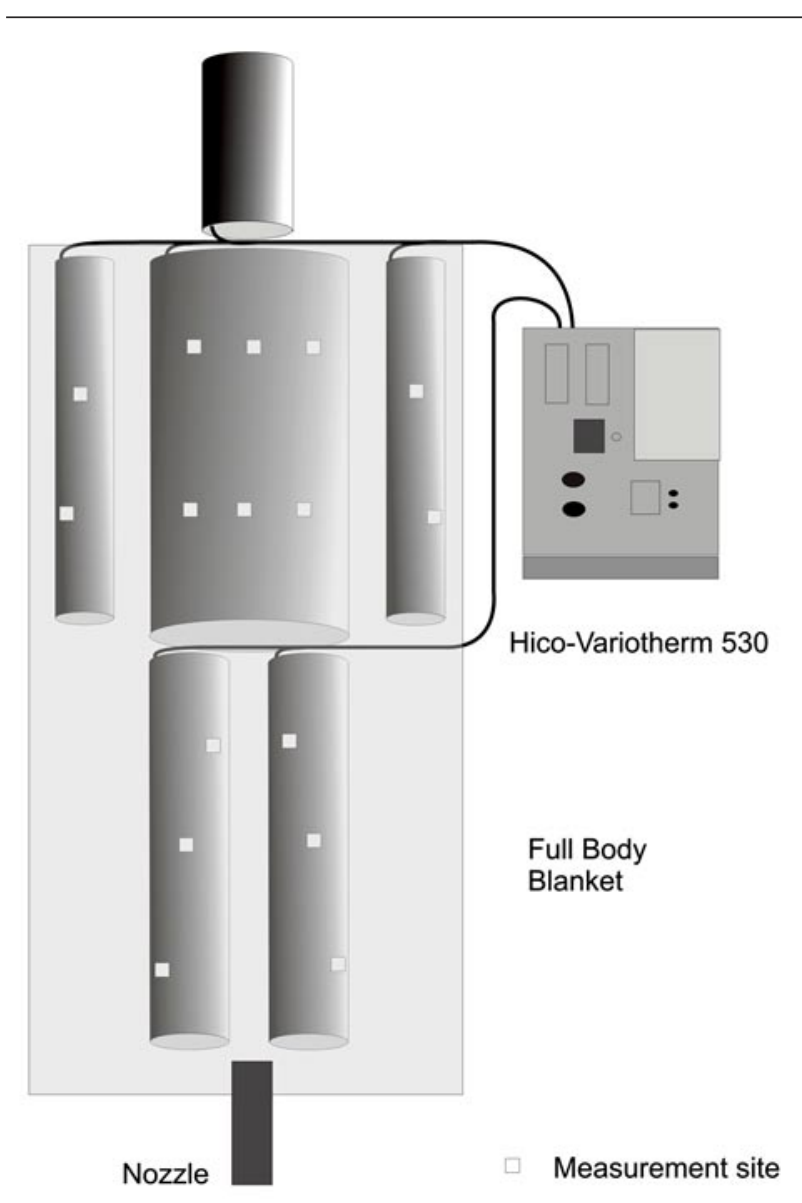

FIGURE 1 Schematic diagram of the manikin and distribution of the 16 measurement sites.

\section{Measurement of heat exchange at the manikin \\ We measured heat flow per unit area between blan- ket surface and the manikin with 16 calibrated heat flux transducers (Heat Flow Sensor Model FR-025- TH44033-F16, Concept Engineering, Old Saybrook, CT, USA).}

\section{Measurement of temperature gradient}

The temperature gradient was defined as the difference between the surface temperature of the manikin underneath the heat flux transducer and the temperature $1 \mathrm{~cm}$ above (blanket temperature). Surface temperature of the manikin was measured with thermistors incorporated into the heat flux sensors. To determine the blanket temperature thermocouple needles (MAT Myocardial sensor $18 \mathrm{~mm}$, Mallinckrodt Medical Inc., St. Louis, MO, USA) were used, so that they made direct contact with the surface of the blanket. Both 
the thermistors and the thermocouples were calibrated before the procedure.

\section{Distribution of measurement sites}

Sixteen measurement sites were distributed on the manikin as follows: two sites were placed on each arm, three sites were placed on each leg and six sites were placed on the trunk (Figure 1). On each measurement site heat exchange at the manikin, manikin surface temperature and blanket temperature were measured.

\section{Data sampling}

Heat flux signals were measured and digitized using a DASH TC AD-converter (Keithley Instruments Inc., Taunton, MA, USA). The thermistors incorporated in the heat flux transducers for measurement of the manikin surface temperature were connected to Hellige Servomed 236039 monitors (Hellige, Freiburg, Germany). Thermocouples for detection of blanket temperature were connected to a second DASH TC A/D-unit. The signal of these monitors was digitized on a DASH 1402 A/D board (Keithley Instruments Inc., Taunton, MA, USA).

\section{Determination of $h$}

To determine the heat exchange coefficient, heat flux per unit area and temperature differences were measured simultaneously over a range of temperature differences. Eight tests were created by using four different surface temperatures of the manikin $\left(27^{\circ} \mathrm{C}, 32^{\circ} \mathrm{C}, 37^{\circ} \mathrm{C}\right.$ and $\left.42^{\circ} \mathrm{C}\right)$, combined with two different blower temperatures (maximum and room temperature). In this way temperature differences of approximately -10 to $+10^{\circ} \mathrm{C}$ were produced. Each test consisted of a 30 -min preparation period to achieve steady state conditions followed by a five-minute measurement period. The collected data were averaged for the single measurement period. In order to randomize the position of blanket perforations in relation to the heat flux transducers each test was repeated three times, each time using a new blanket. The heat exchange coefficient was calculated by linear regression analysis as the slope of heat exchange per unit area as a function of the blanket-surface temperature gradient. The regression line was forced through zero. Heat flux from the blanket to the manikin was called heat gain and was assigned a positive value.

\section{Calculation of mean $\Delta T$ for defined surface tempera-}

tures

The mean $\Delta \mathrm{T}$ is dependent on the surface temperature of the manikin and the efficacy of each single system. To compare the different systems it was necessary to derive a mean $\Delta \mathrm{T}$ for a defined range of manikin surface temperatures. In post-cardiac surgical patients, the mean skin temperature under a forced-air warming blanket ranges between $32^{\circ} \mathrm{C}$ and almost $38^{\circ} \mathrm{C} .{ }^{5,10}$ Therefore, these surface temperatures were chosen to determine the corresponding mean $\Delta \mathrm{T}$. To calculate mean $\Delta \mathrm{T}$, the temperature difference between the blanket and the manikin surface was plotted as a function of the temperature of the manikin surface and a regression line was calculated to define their relationship. The equation of this regression line was used to derive mean $\Delta \mathrm{T}$ for surface temperatures of $32^{\circ} \mathrm{C}$ and $38^{\circ} \mathrm{C}$.

\section{Determination of the covered area}

The area covered by the full body blanket was considered to be the same for all systems. Approximately one third of the trunk and the extremities does not take part in heat exchange by forced-air warming, because this surface is in direct contact with the bed. Therefore the covered area was calculated as two thirds of the circumference times the length of the trunk, arms and legs. This resulted in the following covered areas:

$$
\begin{array}{ll}
\text { Trunk: } & 2 / 3 \cdot 0.84 \mathrm{~m} \cdot 0.74 \mathrm{~m}=0.41 \mathrm{~m}^{2} \\
\text { Arm: } & 2 / 3 \cdot 0.33 \mathrm{~m} \cdot 0.705 \mathrm{~m}=0.16 \mathrm{~m}^{2} \\
\text { Leg: } & 2 / 3 \cdot 0.485 \mathrm{~m} \cdot 0.75 \mathrm{~m}=0.24 \mathrm{~m}^{2} \\
\text { Trunk and extremities: } 1.21 \mathrm{~m}^{2}
\end{array}
$$

\section{Calculation of heat exchange at the manikin}

Heat exchange at the manikin was calculated for surface temperatures of $32^{\circ} \mathrm{C}$ and $38^{\circ} \mathrm{C}$ according to equation $\mathrm{l}$ for each system.

\section{Results}

Mean ambient temperature for all trials was $22.1 \pm$ $0.5^{\circ} \mathrm{C}$, mean relative humidity was $38 \pm 9 \%$ and mean air velocity was $<0.1 \mathrm{~m} \cdot \mathrm{sec}^{-1}$ with no relevant difference between the single measurement series.

\section{Heat flow delivered to the blanket}

The nozzle temperatures ranged between $41.5^{\circ} \mathrm{C}$ and $47.6^{\circ} \mathrm{C}$ and air flow ranged between $9.4 \mathrm{~L} \cdot \mathrm{sec}^{-1}$ and $26.2 \mathrm{~L} \cdot \mathrm{sec}^{-1}$, resulting in heat flows ranging from 249 $\mathrm{W}$ to $623 \mathrm{~W}$ (Table I).

\section{Heat exchange at the manikin}

Total heat flow to the manikin was different for surface temperatures between $32^{\circ} \mathrm{C}$ and $38^{\circ} \mathrm{C}$. At a surface temperature of $32^{\circ} \mathrm{C}$ the heat flows were higher (between 30.7 and $77.3 \mathrm{~W}$ ) than at surface temperatures of $34^{\circ} \mathrm{C}(19.9$ to $58.5 \mathrm{~W})$ or at a surface temperature of $36^{\circ} \mathrm{C}(8.2$ to $44.4 \mathrm{~W})$, or at a surface temperature of $38^{\circ} \mathrm{C}(-8.8$ to $29.6 \mathrm{~W})$. The differ- 
TABLE I Nozzle temperatures, air flows and the resulting heat flow of the power units

\begin{tabular}{|c|c|c|c|}
\hline System & Nozzle temperature $\left({ }^{\circ} \mathrm{C}\right)$ & $\operatorname{Air}$ flow $\left(L \cdot \sec ^{-1}\right)$ & Heat flow $(W)$ \\
\hline Bair Hugger® 505 and full body blanket & 42.8 & 10.7 & 249 \\
\hline Bair Hugger ${ }^{\circledR} 750$ and full body blanket & 41.5 & 26.2 & 623 \\
\hline Life-Air $1000 \mathrm{~S}$ and full body blanket & 43.3 & 15.6 & 380 \\
\hline Snuggle Warm® SW-3000 and full body blanket & 44.5 & 11.9 & 297 \\
\hline Thermacare ${ }^{\circledR}$ and full body blanket & 42.7 & 12.8 & 296 \\
\hline Thermacare ${ }^{\circledR}$ and Optisan $®$ full body blanket & 42.8 & 19.2 & 447 \\
\hline Warm-Gard $®$ and full body blanket & 47.6 & 12.2 & 346 \\
\hline Warm-Gard ${ }^{\circledR}$ and reusable full body blanket & 46.4 & 9.4 & 255 \\
\hline WarmTouch $^{\mathrm{TM}}$ and CareDrape ${ }^{\mathrm{TM}}$ full body blanket & 43.1 & 14.5 & 342 \\
\hline WarmTouch $^{\mathrm{TM}}$ and MultiCover ${ }^{\mathrm{TM}}$ full body blanket & 44.2 & 19.8 & 491 \\
\hline
\end{tabular}

TABLE II Heat exchange coefficients (h), mean temperature gradients at a calculated surface temperature of $32^{\circ} \mathrm{C}(\Delta \mathrm{T}$ at $\left.32^{\circ} \mathrm{C}\right), 34^{\circ} \mathrm{C}\left(\Delta \mathrm{T}\right.$ at $\left.34^{\circ} \mathrm{C}\right), 36^{\circ} \mathrm{C}\left(\Delta \mathrm{T}\right.$ at $\left.36^{\circ} \mathrm{C}\right)$ and $38^{\circ} \mathrm{C}\left(\Delta \mathrm{T}\right.$ at $\left.38^{\circ} \mathrm{C}\right)$ and the resulting heat exchange between the full body blanket and the manikin

\begin{tabular}{|c|c|c|c|c|c|c|c|c|c|}
\hline \multirow[t]{2}{*}{ System } & \multirow{2}{*}{$\begin{array}{c}b \\
\left(W m^{-2}{ }^{-1} C^{-1}\right)\end{array}$} & \multicolumn{4}{|c|}{$\Delta T\left({ }^{\circ} \mathrm{C}\right) a t$} & \multicolumn{4}{|c|}{ Heat exchange $(W)$ at } \\
\hline & & $32^{\circ} \mathrm{C}$ & $34^{\circ} \mathrm{C}$ & $36^{\circ} \mathrm{C}$ & $38^{\circ} \mathrm{C}$ & $32{ }^{\circ} \mathrm{C}$ & $34^{\circ} \mathrm{C}$ & $36^{\circ} \mathrm{C}$ & $38^{\circ} \mathrm{C}$ \\
\hline Bair Hugger® 505 and full body blanket & 21.9 & 1.40 & 0.91 & 0.43 & -0.06 & 30.7 & 19.9 & 11.4 & -1.6 \\
\hline Bair Hugger ${ }^{\circledR} 750$ and full body blanket & 28.0 & 2.76 & 2.09 & 1.31 & 0.53 & 77.3 & 58.5 & 44.4 & 18.0 \\
\hline Life-Air $1000 \mathrm{~S}$ and full body blanket & 26.4 & 1.76 & 1.17 & 0.58 & -0.02 & 46.5 & 30.9 & 18.5 & -0.6 \\
\hline Snuggle Warm ${ }^{\circledR} S W-3000$ and full body blanket & 32.2 & 1.93 & 1.42 & 0.91 & 0.40 & 62.1 & 45.7 & 35.5 & 15.6 \\
\hline Thermacare ${ }^{\circledR}$ and full body blanket & 23.6 & 1.97 & 1.40 & 0.83 & 0.26 & 46.5 & 33.0 & 23.7 & 7.4 \\
\hline Thermacare $\AA^{\circledR}$ and Optisan $\AA$ full body blanket & 17.1 & 2.79 & 2.00 & 1.22 & 0.43 & 47.7 & 34.2 & 25.2 & 8.9 \\
\hline WarmAir ${ }^{\circledR}$ and full body FiltredFlo ${ }^{\mathrm{TM}}$ blanket & 13.4 & 2.61 & 1.83 & 1.05 & 0.27 & 35.0 & 24.5 & 17.0 & 4.4 \\
\hline Warm-Gard® and full body blanket & 15.4 & 3.18 & 2.65 & 2.12 & 1.59 & 49.0 & 40.8 & 39.5 & 29.6 \\
\hline Warm-Gard ${ }^{\circledR}$ and reusable full body blanket & 15.3 & 2.50 & 1.83 & 1.16 & 0.49 & 38.3 & 28.0 & 21.5 & 9.1 \\
\hline WarmTouch $^{\mathrm{TM}}$ and full body blanket & 28.1 & 1.24 & 0.74 & 0.24 & -0.26 & 34.8 & 20.8 & 8.2 & -8.8 \\
\hline WarmTouch $^{\mathrm{TM}}$ and MultiCover ${ }^{\mathrm{TM}}$ full body blanket & 14.5 & 3.18 & 2.46 & 1.74 & 1.02 & 46.1 & 35.7 & 30.5 & 17.9 \\
\hline
\end{tabular}

ences between systems were reflected in the higher mean $\Delta$ Ts at the lower surface temperatures (Table II). The heat exchange coefficients varied by a factor of 2 among the systems and ranged between 13.4 and $32.2 \mathrm{~W} \cdot \mathrm{m}^{-2} \cdot{ }^{\circ} \mathrm{C}^{-1}$. Figure 2 shows a typical example for the determination of $h$ for a single system.

The mean $\Delta \mathrm{T}$ varied between 1.24 and $3.18^{\circ} \mathrm{C}$ for surface temperatures of $32^{\circ} \mathrm{C}$ and between 0.26 and $1.59^{\circ} \mathrm{C}$ for surface temperatures of $38^{\circ} \mathrm{C}$ (Table II). Figure 3 shows a typical example of how mean $\Delta \mathrm{T}$ was derived for the defined surface temperatures.

\section{Discussion}

Postoperative hypothermia after cardiac surgery remains a common problem ${ }^{3-8,11}$ associated with inhibition of platelet function, ${ }^{12}$ coagulation abnormalities, ${ }^{13}$ increasing postoperative blood loss ${ }^{14}$ and an increased need for transfusion of packed red cells. ${ }^{8}$ Hypothermia may also trigger shivering and therefore increase myocardial and circulatory stress, ${ }^{15}$ and can reduce resistance to surgical infections. ${ }^{16}$ Postoperative hypothermia is also associated with prolonged mechanical ventilation, and prolonged intensive care unit and hospital length of stay. ${ }^{8}$ Postoperative rewarming reduces shivering ${ }^{11}$ and enables earlier extubation. ${ }^{7}$

Forced-air warming is a common method for rewarming after cardiac surgery. In 1994 Giesbrecht et al. ${ }^{17}$ described significant differences between forced-air warming devices in combination with full body blankets. However, the clinical relevance of these results from a study of normothermic volunteers is uncertain, as the skin temperature of normothermic volunteers is generally higher than the mean skin temperatures of hypothermic postoperative cardiac surgical patients. Therefore, we investigated the heat transferring properties of 11 forced air warming systems with full body blankets using a validated copper manikin at temperatures reflective of the early postoperative setting. This manikin has been used previously for comparison of forced-air warming systems with upper ${ }^{18}$ or lower body blankets. ${ }^{19}$ 


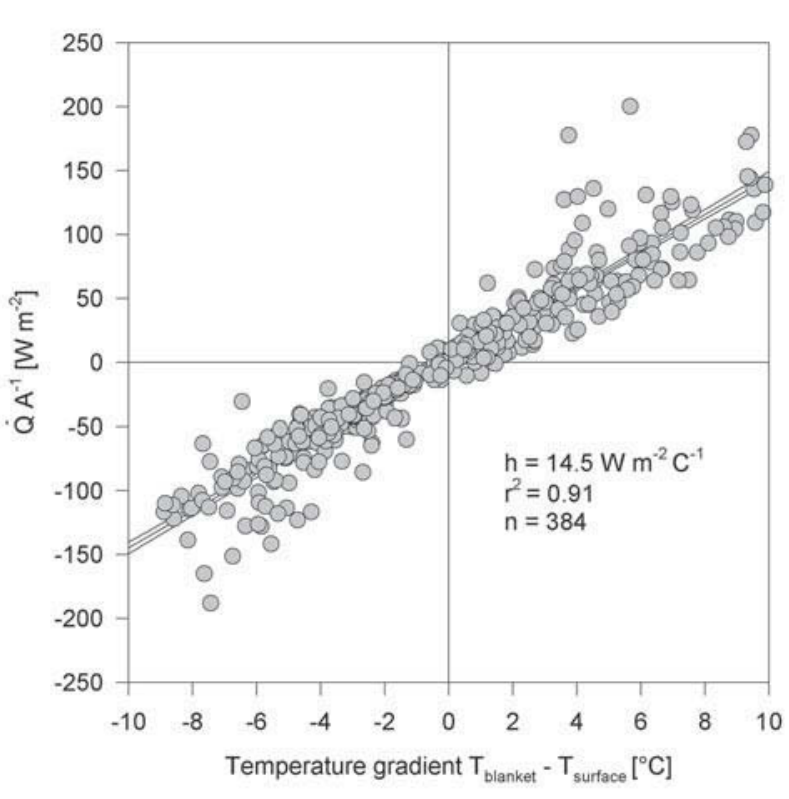

FIGURE 2 Determination of the heat exchange coefficient of the WarmTouch ${ }^{\mathrm{TM}} 5800$ warming unit and MultiCover ${ }^{\mathrm{TM}}$ full body blanket. The heat exchange coefficient was calculated by linear regression analysis as the slope of heat exchange per unit area as a function of the blanket-surface temperature gradient. Regression line and 95\% confidence intervals.

We found relevant differences in heat transfer between the different forced-air warming systems tested. Heat transfer ranged between 30.6 to $77.3 \mathrm{~W}$ for surface temperatures of $32^{\circ} \mathrm{C}$, and between -8.8.to $29.6 \mathrm{~W}$ for surface temperatures of $38^{\circ} \mathrm{C}$. This divergence in heat transfer at different surface temperatures is caused by the higher mean temperature gradient between the blanket and the manikin surface. This effect can be observed with every system, and limits heat transfer to an already warm surface temperature.

Three forced-air warming systems failed to maintain a positive temperature gradient between the blanket and the manikin surface at a surface temperature of $38^{\circ} \mathrm{C}$ and as a result, cooled the manikin. However, our results are at variance with those of Giesbrecht et al. ${ }^{17}$ who found a heat transfer of 40 to $95 \mathrm{~W}$. There are three possible explanations for the differences between their study and ours: 1) mean skin temperatures may not have been comparable; 2 ) our manikin may be limited in its ability to simulate realistic conditions for forced-air warming devices; and 3) forced-air warming systems have evolved during the 13-yr interval between these studies.

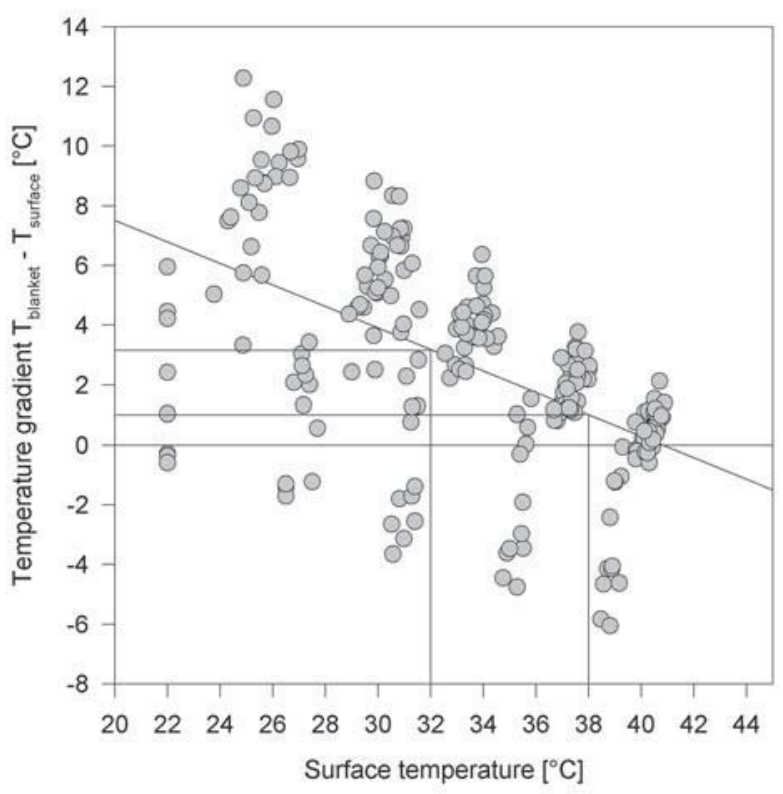

FIGURE 3 Determination of mean $\Delta \mathrm{T}$ for the WarmTouch $^{\mathrm{TM}} 5800$ warming unit and MultiCover ${ }^{\mathrm{TM}}$ full body blanket. To calculate mean $\Delta \mathrm{T}$ the temperature difference between the blanket and the manikin surface was plotted as a function of the temperature of the manikin surface and a regression line calculated to define their relationship. The equation of this regression line was used to derive mean $\Delta \mathrm{T}$ for surface temperatures of $32^{\circ} \mathrm{C}$ and $38^{\circ} \mathrm{C}$.

In the study of Giesbrecht et al. mean skin temperature under the forced-air warming system ranged between $36.5^{\circ} \mathrm{C}$ and $37.5^{\circ} \mathrm{C} .{ }^{17}$ In post-cardiac surgery patients $5^{5,10}$ the mean skin temperature under a forcedair warming blanket rises slowly from $32^{\circ} \mathrm{C}$ to almost $38^{\circ} \mathrm{C}$, and we have calculated heat transfer values to reflect the response at these surface temperatures. Therefore, the testing conditions of the studies were not comparable. However, as the temperature gradient between the blanket and the surface was higher at lower surface temperatures, we would have expected higher heat transfers in our study. When comparing the heat transfer values from our study at surface temperatures of $36^{\circ} \mathrm{C}$ to $38^{\circ} \mathrm{C}$ to the heat transfers observed by Giesbrecht et al., ${ }^{17}$ the difference becomes even greater. Here we can only see heat transfers from -8.8 to $44 \mathrm{~W}$ (Table II), which is much less than 40 to 95 W observed by Giesbrecht et al. ${ }^{17}$ Accordingly, the different testing conditions cannot alone account for the different findings of these two studies.

The heat exchanging properties of this manikin model have been carefully validated. ${ }^{20}$ The combined 
heat exchange coefficient for radiation and convection of the manikin is $11 \mathrm{~W} \cdot \mathrm{m}^{-2} \cdot{ }^{\circ} \mathrm{C}^{-1}$. This corresponds well with the combined heat exchange coefficient for radiation and convection of $10.8 \mathrm{~W} \cdot \mathrm{m}^{-2} \cdot{ }^{\circ} \mathrm{C}^{-1}$ that was measured previously in human volunteers using the same methodology. ${ }^{20}$ The emissivity of the manikin is 0.96 , whereas the emissivity of human skin is $0.98 .^{21}$ In a previous study in volunteers, we tested four different forced-air warming systems with upper body blankets ${ }^{22}$ and demonstrated that we could confidently predict the heat transfer of these forced-air warmers with a previous investigation in manikins. ${ }^{18}$ The heat transfer of three forced-air warming systems could be predicted exactly, whereas a fourth system was underestimated by $1.1 \mathrm{~W}$, a value which is of minimal clinical importance. Therefore, the manikin is able to accurately simulate heat transfer of forced-air warming systems.

Discrepancies between studies may also reflect, to a certain degree, advances in the technology of forcedair warming systems which have taken place over the past decade. In the early 90's forced-air warming devices were used primarily for postoperative rewarming of conscious hypothermic patients. This application allowed for higher nozzle temperatures of the power units than today. In an unpublished series in 1994 we found that the Bair Hugger® 200 had a nozzle temperature of $51.3^{\circ} \mathrm{C}$, the WarmAir ${ }^{\circledR} 133$ power unit used a nozzle temperature of $45.0^{\circ} \mathrm{C}$ and the WarmTouch $^{\mathrm{TM}}$ had a nozzle temperature of $48.8^{\circ} \mathrm{C}$. The air flows of these earlier devices were also much higher than in the series of warming devices from the current investigation, where flow rates ranged between $17.4 \mathrm{~L} \cdot \mathrm{sec}^{-1}$ to $31.5 \mathrm{~L} \cdot \mathrm{sec}^{-1}$.

The increasing intraoperative use of forced-air warming systems has led to a reduction of nozzle temperatures, because there are reports of burns associated with the use of forced-air warming systems. ${ }^{23}$ Another factor to consider is that most forced-air warming systems operate with a lower air flow in Europe compared to North America, because the AC power source in Europe uses $50 \mathrm{~Hz}$, compared to 60 $\mathrm{Hz}$ in North America. The motors of most forced-air warming systems operate at reduced speed at $50 \mathrm{~Hz}$, which decreases the air flow of the blower by approximately $20 \%$. Only the motor of the Bair Hugger ${ }^{\circledR}$ Model 750 operates at the same speed at either 50 $\mathrm{Hz}$ or $60 \mathrm{~Hz}$.

Finally, the higher nozzle temperatures and air flows from warming devices of the 1990s may explain why the heat transfer values in the investigation of Giesbrecht $e t$ $a l .{ }^{17}$ were higher than in our investigation, although Giesbrecht et al. did not report these data.
In conclusion, the evaluation of commercially available forced-air warming devices using a validated manikin model demonstrates clinically relevant differences between systems.

Several systems were unable to provide adequate heat transfer to the manikin at a surface temperature of $38^{\circ} \mathrm{C}$.

\section{Acknowledgement}

We sincerely thank Dr. Elke Kahler of the Department of Medical Statistics for her assistance with the statistical interpretation.

\section{References}

1 Rajek A, Lenhardt R, Sessler DI, et al. Efficacy of two methods for reducing postbypass afterdrop. Anesthesiology 2000; 92: 447-56.

2 Joachimsson PO, Nystrom SO, Tyden H. Postoperative ventilatory and circulatory effects of extended rewarming during cardiopulmonary bypass. Can J Anaesth 1989; 36: 9-19.

3 Harrison SJ, Ponte J. Convective warming combined with vasodilator therapy accelerates core rewarming after coronary artery bypass surgery. $\mathrm{Br} \mathrm{J}$ Anaesth 1996; 76: 511-4.

4 Villamaria FJ, Baisden CE, Hillis A, Rajab MH, Rinaldi $P A$. Forced-air warming is no more effective than conventional methods for raising postoperative core temperature after cardiac surgery. J Cardiothorac Vasc Anesth 1997; 11: 708-11.

5 Janke EL, Pilkington SN, Smith DC. Evaluation of two warming systems after cardiopulmonary bypass. $\mathrm{Br} \mathrm{J}$ Anaesth 1996; 77: 268-70.

6 Hanbela R, Mustonen A, Korbonen I, Salomaki T. The effects of two rewarming strategies on heat balance and metabolism after coronary artery bypass surgery with moderate hypothermia. Acta Anaesthesiol Scand 1999; 43: 979-88.

7 Pathi V, Berg GA, Morrison J, Cramp G, McLaren D, Faichney $A$. The benefits of active rewarming after cardiac operations: a randomized prospective trial. J Thorac Cardiovasc Surg 1996; 111: 637-41.

8 Insler SR, O'Connor MS, Leventhal MJ, Nelson DR, Starr NJ. Association between postoperative hypothermia and adverse outcome after coronary artery bypass surgery. Ann Thorac Surg 2000; 70: 175-81.

9 Weast RC. Handbook of Chemistry and Physics. A Ready-Reference Book of Chemical and Physical Data, $56^{\text {th }}$ ed. Cleveland, Ohio: CRC Press; 1975.

10 Sanford $M M$. Rewarming cardiac surgical patients: warm water vs warm air. Am J Crit Care 1997; 6: 39-45.

11 Joachimsson PO, Nystrom SO, Tyden H. Heating efficacy of external heat supply during and after open-heart sur- 
gery with hypothermia. Acta Anaesthesiol Scand 1987; 31: $73-80$.

12 Valeri CR, Khabbatz K, Khuri SF, et al. Effect of skin temperature on platelet function in patients undergoing extracorporeal bypass. J Thorac Cardiovasc Surg 1992; 104: 108-16.

13 Rohrer MJ, Natale AM. Effect of hypothermia on the coagulation cascade. Crit Care Med 1992; 20: 1402-5.

14 Hohn L, Schweizer A, Kalangos A, Morel DR, Bednarkiewicz M, Licker M. Benefits of intraoperative skin surface warming in cardiac surgical patients. $\mathrm{Br} \mathrm{J}$ Anaesth 1998; 80: 318-23.

15 Licker M, Hohn H, Ralley FR. Relation between systemic oxygen uptake and tissue oxygen extraction following cardiac surgery. Eur J Anaesthesiol 1996; 13: $562-70$.

16 Kurz A, Sessler DI, Lenhard R. Perioperative normothermia to reduce the incidence of surgical-wound infection and shorten hospitalization. Study of Wound Infection and Temperature Group. N Engl J Med 1996; 334: 1209-15.

17 Giesbrecht GG, Ducharme MB, McGuire JP. Comparison of forced-air patient warming systems for perioperative use. Anesthesiology 1994; 80: 671-9.

18 Braner A, English MJ, Steinmetz N, et al. Comparison of forced-air warming systems with upper body blankets using a copper manikin of the human body Acta Anaesthesiol Scand 2002; 46: 965-72.

19 Braner A, English MJ, Lorenz N, et al. Comparison of forced-air warming systems with lower body blankets using a copper manikin of the human body. Acta Anaesthesiol Scand 2003; 47: 58-64.

20 Braner A, English MJ, Sander H, Timmermann A, Braun $U$, Weyland $W$. Construction and evaluation of a manikin for perioperative heat exchange. Acta Anaesthesiol Scand 2002, 46: 43-50.

21 Burton AC, Edholm OG. Man in a Cold Environment. London: Edward Arnold Publishers; 1955.

22 Perl T, Braner A, Timmermann A, Mielck F, Weyland $W$, Braun $U$. Differences among forced-air warming systems with upper body blankets are small. A randomized trial for heat transfer in volunteers. Acta Anaesthesiol Scand 2003; 47: 1159-64.

23 Azzam FJ, Krock JL. Thermal burns in two infants associated with a forced air warming system. Anesth Analg 1995; 81: 661. 